\title{
High serum 8-hydroxy-2'-deoxyguanosine levels predict DNA damage and aging in professional divers
}

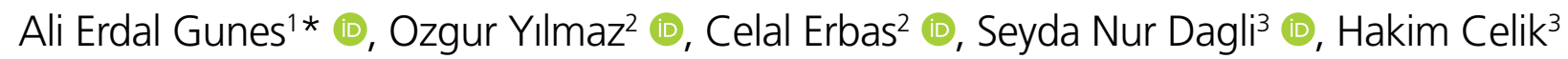

\section{SUMMARY}

OBJECTIVE: Reactive oxygen species and oxygen free radicals cause oxidative damage to lipids, proteins, and cell DNA in the cell membrane. Although many DNA products are produced during oxidative DNA damage, 8-hydroxy-2'-deoxyguanosine (8-OHdG) is the most common one, since it can be produced in in vivo environment. In recent years, diving has been done quite frequently for business and sports purposes all over the world. Increased environmental pressure in diving leads to hyperoxia and causes oxidative stress.

METHODS: The acute effects of diving on DNA damage were evaluated by comparing 8-hydroxy-2'-deoxyguanosine values of 15 professional diver groups before and after diving. In addition to the demographic characteristics, the serum 8-hydroxy-2'-deoxyguanosine levels of these 15 divers were compared with the control group consisting of nondiving medical students to examine the chronic effect of diving on DNA damage.

RESULTS: After deep dive, the amount of 8-hydroxy-2'-deoxyguanosine increased significantly in the diver group and acute DNA damage was observed (T1: 38.86 $\pm 4.7 ; \mathrm{T} 2: 51.77 \pm 4.53 ; \mathrm{p}<0.05)$. In the control group, the amount of 8 -hydroxy-2'-deoxyguanosine was insignificant (C1: 47.48 $\pm 3.73 ; \mathrm{T1}: 38.86 \pm 4.7 ; \mathrm{p}>0.05$ ).

CONCLUSIONS: It was found that air dives caused an increase in serum 8-hydroxy-2'-deoxyguanosine levels, leading to acute oxidative stress and aging. However, there is no chronic side effect, according to the study of samples taken from the control group. This was thought to be due to the relative sedentary life of the control group. The duration of the effect or the ability to return to normal values should be investigated with further studies planned with large populations.

KEYWORDS: 8-Hydroxy-2'-deoxyguanosine. Air pressure. Naval medicine. DNA damage. Diving.

\section{INTRODUCTION}

Exposure of some workers and healthcare workers to hyperbaric environment means breathing air at high pressure of more than $10 \%$ of $1 \mathrm{~atm}$. Operations in hyperbaric environments can take place in wet environments such as tunnels, tunnel scraping and pressure chambers, and search-rescue and military purposes ${ }^{1}$.

According to Henry's gas law, limited depth and time of the dive is suggested to avoid oxygen toxicity during diving $^{2}$. Witte et al. reported DNA damage increases with depth and bottom time during diving ${ }^{3}$. These partial pressure changes of oxygen and nitrogen in body tissues are responsible for many biochemical reactions that cause the formation of reactive oxygen and reactive nitrogen species ${ }^{4}$. These radicals cause a decrease in the activities of antioxidant enzymes, leading to lipid peroxidation in the cell membrane with DNA damage.

Some metabolomics have been used successfully in assessing the health status of workers at environmental exposures 5 8-Hydroxy-2'-deoxyguanosine (8-OHdG), which is the most

\footnotetext{
${ }^{1}$ Harran University, School of Medicine, Department of Underwater and Hyperbaric Medicine - Sanliurfa, Turkey.

${ }^{2}$ Cukurova University, Yumurtalik Vocational School, Underwater Technology Programme - Adana, Turkey.

${ }^{3}$ Harran University, School of Medicine, Department of Medical Physiology - Sanliurfa, Turkey.

*Corresponding author: aerdalg@gmail.com

Conflicts of interest: the authors declare there is no conflicts of interest. Funding: none.

Received on August 09, 2021. Accepted on August 30, 2021.
} 
common metabolomics in the oxidative damage of DNA, is a sensitive biomarker that can show even low-level DNA damage of oxidative stress ${ }^{6}$. It is formed when the hydroxyl radical damages the guanidine nucleoside at the $\mathrm{C} 8$ position on the DNA or when the hydroxyl radical binds to deoxyguanidine with receiver electron?

The studies on DNA damage in the hyperbaric environment remain challenging. In fact, this study is the first to examine 8-OHdG levels after air diving. In a previous study, we showed that single deep diving in the dry hyperbaric environment can cause thiol-disulfide imbalance in divers ${ }^{8}$. In addition to the high oxygen levels, the increasing number of workers in pressurized environments and the water temperature can also cause increase oxidative DNA damage ${ }^{9}$. Therefore, this study aims to investigate and identify the negative impact of environmental factors on health and cellular aging of individuals exposed to hyperbaric environment throughout their professional life.

\section{METHODS}

The experimental protocol was approved by the local ethics committee of the Harran University (2018/09/12) and was planned in accordance with the Helsinki Declaration. The study was planned with the control group, and the samples were taken before and after the application.

\section{Study population}

A total of 35 healthy volunteers (34 males and 1 female) participated in this study. Based on the demographic characteristics, participants were divided into study and control groups. The study group consisted of 17 volunteer professional divers (16 males and 1 female, 20.6 \pm 0.8 years) graduated from professional underwater diving school and were exposed to hyperbaric hyperoxic environment. The control group consisted of 18 volunteer male medical students ( $19.4 \pm 0.3$ years) who did not do any diving and were included as the control group. Informed consent with personal information and health status was obtained from all volunteers and was kept confidential. Inclusion criteria of participants were nonsmokers, nonalcoholics, without any chronic disease (e.g., orthopedic, heart, kidney, liver, autoimmune, and metabolic diseases), and no history of any medication use. A diet and sleep plan was prepared for all volunteers 7 days prior to the study. All participants should not have any travel history during this period. Before the dive, only light breakfast was given to the participants (17 divers). Volunteer divers had $162 \mathrm{~h}$ of self-contained scuba apparatus, $192 \mathrm{~h}$ surface supplied breathing apparatus, and $28 \mathrm{~h}$ pressure room diving experience.

\section{Study design and diving session}

Fifteen minutes before the hyperbaric environment exposure, a blood sample was taken from all divers to examine whether the chronic hyperbaric exposure caused DNA damage. Then, blood samples taken $1 \mathrm{~h}$ after diving and before diving were compared to examine whether the dive caused acute damage to DNA.

Hyperbaric hyperoxic exposure was planned inside the decompression chamber as a dry (Barotech Multi DK 1700, Istanbul, Turkey). The Dive Plan was planned according to the U.S. Navy Air dive profile with zero deco limits. The divers were planned as a group of quaternaries and the first dive was made at 40 meter sea water $(\mathrm{msw})$ at 11:00 a.m. with $5 \mathrm{~min}$ bottom time. The ascent rate was set at $10 \mathrm{~m} / \mathrm{min}$, at the end of the dive; a 3-min safety deco was applied at $5 \mathrm{msw}$. The first dive was completely ended at 11:15 a.m. The other groups were taken to the chamber in turn according to the plan.

During the dive, the temperature was kept constant at $25^{\circ} \mathrm{C}$ depending on the temperature in the pressure chamber and the indoor air was continuously analyzed and ventilated during the dive. A light and tempo walking and on-site movement were planned for volunteer divers during the chamber dive to imitate the stress factors in wet diving.

\section{Sample collections and 8-hydroxy-2'- deoxyguanosine analysis}

The antecubital vein was selected for sample collection from all participants. Samples were taken from the divers $90 \mathrm{~min}$ before the dive (T1) and $90 \mathrm{~min}$ after the dive (T2). The samples of the control group (C1) are the same as the time of $\mathrm{T} 1$ samples. Immediately after the blood was taken into tubes, it was centrifuged at $2,000 \mathrm{~g}$ (Hettich, Universal 320R, Tuttlingen, Germany) and the sampling serum was obtained. It was stored at $-80^{\circ} \mathrm{C}$ for commercial kits application.

To measure the levels of 8-OHdG in samples, the commercial enzyme-linked immunosorbent assay (ELISA) (Lot No: WXCYJEGD8D, Elabscience, Houston, TX, USA) commercial kit procedure was applied.

The sera stored in suitable storage conditions were dissolved to room temperature $\left(+18-25^{\circ} \mathrm{C}\right)$. After the samples were loaded into $50 \mu \mathrm{l}$ wells, $50 \mu \mathrm{l}$ of biotin was added and incubated at $+37^{\circ} \mathrm{C}$ for $45 \mathrm{~min}$. After aspirating and washing three times, $100 \mu \mathrm{l}$ of conjugate liquid was added and incubated for $30 \mathrm{~min}$ at $+37^{\circ} \mathrm{C}$. The sera were aspirated again, washed three times, and finally incubated with $90 \mu \mathrm{l}$ of the substrate at $+37^{\circ} \mathrm{C}$ for $15 \mathrm{~min}$. In the final stage, $50 \mu \mathrm{l}$ of stop solution was added to the sera and the results were calculated by measuring at $450 \mathrm{~nm}$. 


\section{Statistical analysis}

Statistical analysis was performed using the Statistical Package for the Social Sciences for Windows software version 22.0 (IBM Inc., Chicago, IL, USA). Data are expressed as mean and standard deviation. Laboratory findings were evaluated with the "ShapiroWilk" test to determine whether they were normally distributed.

\section{RESULTS}

The demographic and anthropometric characteristics of the volunteers participated in the study are given in Table 1 . There was no statistically significant difference in the demographic and anthropometric values between the two groups $(\mathrm{p}>0.05)$.

To examine the chronic effects of hyperbaric environment exposure on DNA damage, the 8-OHdG levels in serum taken from the $\mathrm{C} 1$ group and the $\mathrm{T} 1$ group were compared and found to be statistically insignificant $(\mathrm{C} 1: 47.48 \pm 3.73 ; \mathrm{T} 1: 38.86 \pm 4.7$, $\mathrm{p}>0.05$ ) (Table 2).

To examine the acute effects of hyperbaric environment exposure on DNA damage, the 8-OHdG levels in serum samples taken from the $\mathrm{T} 1$ group and the $\mathrm{T} 2$ group were compared. The levels after the dive were higher than those before the dive, and this difference was statistically significant (T1: 38.86 \pm 4.7 ; T2: 51.77 $\pm 4.53, \mathrm{p}<0.05$ ) (Table 3).

\section{DISCUSSION}

The aim of this study is to show whether hyperbaric environment exposure causes damage to DNA in divers. We planned a single air dive to a depth of $40 \mathrm{msw}$ to assess DNA damage during acute hyperbaric exposure in divers. The reason for choosing $40 \mathrm{msw}$ is to measure the partial pressure of oxygen in the inhaled air as $1 \mathrm{~atm}$. Also, $40 \mathrm{msw}$ depth is the upper limit of recreational diving. We also aimed to make inferences about sport, recreational, and professional diving. According to the results, although single-session deep diving caused acute damage to DNA, this damage did not continue when divers were not involved in diving.

Factors causing increased DNA damage include stress factors such as increased environmental pressure, compressed gas breathing, and claustrophobia in dry hyperbaric environment exposure, and stream-cloudy water and hot-cold water in wet diving. Similar to underwater exercise, during the dive, the divers do a light walk and on-site movement in the pressure chamber. Tranfo et al. found that hypoxanthine levels were higher in the wet environment than in the dry hyperbaric environment ${ }^{1}$. Bosco et al. showed that the exposure to wet hyperbaric environment caused stress with hot diving water and underwater cycling, and increased urinary $8-\mathrm{OHdG}$ lev$\mathrm{els}^{10}$. As mentioned previously, the exercise given to the divers in a single-session hyperbaric environment exposure caused an increase in 8-OHdG levels, leading to DNA damage.

$8-\mathrm{OHdG}$ is a biomarker of oxidative stress and aging which can be analyzed through urea, organs, and leukocyte DNA ${ }^{11}$. 8-OHdG is the most common product of oxidative DNA damage $^{12}$. In addition, increased levels of 8-OHdG are responsible for cardiovascular risk and endothelial dysfunction ${ }^{6}$. High levels of 8-OHdG have been shown to impair renal function, with inflammatory markers ${ }^{6}$.

Table 1. Demographic and anthropometric characteristics of study population.

\begin{tabular}{l|c|c|c|c}
\hline Subject & Age & Height $(\mathrm{m})$ & Mass $(\mathrm{kg})$ & $\mathrm{BMI}\left(\mathrm{kg} / \mathrm{m}^{2}\right)$ \\
\hline Control group (medical students) $\mathrm{n}=18$ & $19.4 \pm 0.3$ & $1.74 \pm 10.6$ & $66 \pm 12.5$ & $23.7 \pm 2.2$ \\
\hline Study group (professional diver group) $\mathrm{n}=17$ & $20.6 \pm 0.8$ & $1.71 \pm 11.8$ & $63 \pm 11.9$ & $22.8 \pm 1.6$ \\
\hline $\mathrm{p}$-value & 0.081 & 0.057 & 0.61 & 0.066 \\
\hline
\end{tabular}

Values are presented as mean \pm SD. Statistically significant at $p>0.05$.

Table 2. Comparison of serum 8-hydroxy-2'-deoxyguanosine levels before the dive (T1) of control group and study group.

\begin{tabular}{l|c|c|c}
\hline Subject & Control group (C1) & Study group (T1) & p-value \\
\hline 8-Hydroxy-2'-deoxyguanosine serum level & $47.48 \pm 3.73$ & $38.86 \pm 4.7$ & 0.20 \\
\hline
\end{tabular}

$\mathrm{T} 1 / \mathrm{C} 1=\mathrm{p}>0.05$. Values are presented as mean $\pm \mathrm{SD}$.

Table 3. Comparison of serum 8-hydroxy-2'-deoxyguanosine levels of study group $1 \mathrm{~h}$ before diving and $1 \mathrm{~h}$ after diving.

\begin{tabular}{l|c|c|c}
\hline Subject & $\begin{array}{c}\text { Study group } \\
\text { (T1 before exposure) }\end{array}$ & $\begin{array}{c}\text { Study group } \\
\text { (T2 after exposure) }\end{array}$ & p-value \\
\hline 8-Hydroxy-2'-deoxyguanosine serum level & $38.86 \pm 4.7$ & $51.77 \pm 4.53$ & 0.02 \\
\hline
\end{tabular}

$\mathrm{T} 1 / \mathrm{T} 2=\mathrm{p}<0.05$. Values are presented as mean $\pm \mathrm{SD}$. 
It has been shown that homocysteine increases due to oxidative stress in saturation dives where exposure to a hyperbaric environment lasted for days and weeks ${ }^{13}$, and circulating vitamins B6 and B12 and folate levels decrease ${ }^{14}$. This hyperoxic environment causes increased iron stores and decreased erythropoietin levels ${ }^{15}$. The decrease in folate acts as an antioxidant in the oxidative stress environment ${ }^{16}$. A previous study showed that oxidative stress and DNA damage return to normal values with the end of the dive ${ }^{17}$. Our study shows that the $8-\mathrm{OHdG}$ levels of $\mathrm{C} 1 / \mathrm{T} 1$ were statistically insignificant, which is consistent with the results of the previous study.

Oxidative stress causes damage by disrupting the structure of enzymes in the mitochondrial membrane and the tertiary structure and functions of proteins ${ }^{18}$. Brain aging occurs with the formation of $8-\mathrm{OHdG}$ and increased oxidative damage to $\mathrm{mtDNA}^{18}$. In addition, mitochondrial damage due to oxidative stress in brain tissue has been associated with aging and Alzheimer's disease ${ }^{19}$.

Aerobic exercise in a hyperbaric environment has been shown to increase serum lactate levels ${ }^{20}$. In another study, oxidative DNA damage has been shown to cause pulmonary injury ${ }^{21}$. It has also been shown that DNA damage and subsequent serum 8 -OHdG levels increase chronic fatigue syndrome ${ }^{22}$. As can be seen, DNA damage caused by oxidative stress results in aging that affects the whole body.

Some restraints should be considered in the assessment of our study. In this regard, our study was mostly conducted on male samples. To simulate warm water diving, oxidative DNA damage could be increased by turning off the air conditioner in the pressure chamber. Finally, since it is a cross-sectional study, no conclusion can be drawn between $8-\mathrm{OHdG}$ levels and long-term hyperbaric exposure.

\section{CONCLUSIONS}

We studied the effect of occupational and environmental hyperbaric exposures on the formation of 8-OHdG. From a practical point of view, it may be suggested that DNA damage occurs in the early stages of diving and its effects are seen in many tissues in our body. Although there is no DNA damage in daily life in divers with high dive time record in this study, there is a need for multicenter studies with wider interpretation.

\section{ACKNOWLEDGMENTS}

The authors thank all students and professional divers who participated in the study.

\section{AUTHORS" CONTRIBUTIONS}

AEG: Conceptualization, Investigation, Methodology, Project administration, Validation, Writing - original draft, Writing review \& editing. OY: Conceptualization, Methodology, Resources, Supervision. CE: Investigation, Supervision. SND: Data curation, Formal analysis, Writing - review \& editing. HC: Data curation, Formal analysis, Resources, Software, Validation, Visualization.

\section{REFERENCES}

1. Tranfo G, Marchetti E, Pigini D, Miccheli A, Spagnoli M, Sciubba $F$, et al. Targeted and untargeted metabolomics applied to occupational exposure to hyperbaric atmosphere. Toxicol Lett. 2020;328:28-34. https://doi.org/10.1016/j.toxlet.2020.03.022

2. NOAA Diving Manual. Diving for Science and Technology. 6th ed. North Palm Beach: Best Publishing Company; 2017.

3. Witte J, Kähler W, Wunderlich T, Radermacher P, Wohlrab C, Koch A. Dose-time dependency of hyperbaric hyperoxia-induced DNA strand breaks in human immune cells visualized with the comet assay. Undersea Hyperb Med. 2014;41:171-81. PMID: 24984312

4. Gröger M, Oter S, Simkova V, Bolten M, Koch A, Warninghoff $V$, et al. DNA damage after long-term repetitive hyperbaric oxygen exposure. J Appl Physiol (1985). 2009;106(1):311-5. https://doi.org/10.1152/japplphysiol.90737.2008

5. Vermeulen R. The use of high-resolution metabolomics in occupational exposure and health research. Ann Work Expo Health. 2017;61(4):395-7. https://doi.org/10.1093/ annweh/wxx016
6. Dai L, Watanabe M, Qureshi AR, Mukai H, Machowska A Heimbürger $O$, et al. Serum 8-hydroxydeoxyguanosine, a marker of oxidative DNA damage, is associated with mortality independent of inflammation in chronic kidney disease. Eur J Intern Med. 2019;68:60-5. https://doi.org/10.1016/j. ejim.2019.07.035

7. Kasai H, Nishimura S. Hydroxylation of deoxy guanosine at the C-8 position by polyphenols and aminophenols in the presence of hydrogen peroxide and ferric ion. Gan. 1984;75(7):565-6. PMID: 6468841

8. Gunes AE, Çelik H, Yilmaz O, Erbaş C, Gumus E. Acute and chronic effects of pressure on dynamic thiol-disulfide homeostasis in divers. Fresenius Environmental Bulletin. 2019;28(4):2949-56.

9. Gronow G, Kähler W, Koch A, Klause N. Benzoate hydroxylation: a measure of oxidative stress in divers. Adv Exp Med Biol. 2005;566:223-9. https://doi.org/10.1007/0387-26206-7_30 
10. Bosco G, Rizzato A, Quartesan S, Camporesi E, Mrakic-Sposta S, Moretti S, et al. Spirometry and oxidative stress after rebreather diving in warm water. Undersea Hyperb Med. 2018;45(2):191-8. PMID: 29734571

11. Comparison of different methods of measuring 8-oxoguanine as a marker of oxidative DNA damage. ESCODD (European Standards Committee on Oxidative DNA Damage). Free Radic Res. 2000;32(\$):333-41. https://doi.org/10.1080/10715760000300331

12. Shibutani S, Takeshita M, Grollman AP. Insertion of specific bases during DNA synthesis past the oxidation-damaged base 8-oxodG. Nature. 1991;349(6308):431-4. https://doi. org/10.1038/349431a0

13. Ho PI, Ortiz D, Rogers E, Shea TB. Multiple aspects of homocysteine neurotoxicity: glutamate excitotoxicity, kinase hyperactivation and DNA damage. J Neurosci Res. 2002;70(5):694-702. https://doi.org/10.1002/jnr.10416

14. Zwart SR, Kala G, Smith SM. Body iron stores and oxidative damage in humans increased during and after a 10- to 12-day undersea dive. J Nutr. 2009;139(1):90-5. https://doi. org/10.3945/jn.108.097592

15. Rice $L$, Alfrey $C P$. The negative regulation of red cell mass by neocytolysis: physiologic and pathophysiologic manifestations. Cell Physiol Biochem. 2005;15(6):245-50. https://doi. org/10.1159/000087234

16. Gliszczyńska-Swigo A, Muzolf M. pH-dependent radical scavenging activity of folates. J Agric Food Chem. 2007;55(20):8237-42. https://doi.org/10.1021/jf070986x
17. Zwart SR, Jessup JM, Ji J, Smith SM. Saturation diving alters folate status and biomarkers of DNA damage and repair. PLoS One. 2012;7(2):e31058. https://doi.org/10.1371/journal. pone.0031058

18. Mecocci P, Boccardi V, Cecchetti R, Bastiani P, Scamosci M, Ruggiero $C$, et al. A long journey into aging, brain aging, and Alzheimer's disease following the oxidative stress tracks. Alzheimers Dis. 2018;62(3):1319-35. https://doi.org/10.3233/ JAD-170732

19. Ansari MA, Scheff SW. Oxidative stress in the progression of Alzheimer disease in the frontal cortex. J Neuropathol Exp Neurol. 2010;69(2):155-67. https://doi.org/10.1097/ NEN.0b013e3181cb5af4

20. Stellingwerff T, Glazier L, Watt MJ, LeBlanc PJ, Heigenhauser GJF, Spriet LL. Effects of hyperoxia on skeletal muscle carbohydrate metabolism during transient and steady-state exercise. J Appl Physiol (1985). 2005;98(1):250-6. https://doi.org/10.1152/ japplphysiol.00897.2004

21. Barker GF, Manzo ND, Cotich KL, Shone RK, Waxman AB. DNA damage induced by hyperoxia: quantitation and correlation with lung injury. Am J Respir Cell Mol Biol. 2006;35(3):27788. https://doi.org/10.1165/rcmb.2005-03400C

22. Fulle S, Mecocci P, Fanó G, Vecchiet I, Vecchini A, Racciotti D, et al. Specific oxidative alterations in vastus lateralis muscle of patients with the diagnosis of chronic fatigue syndrome. Free Radic Biol Med. 2000;29(12):1252-9. https://doi.org/10.1016/ s0891-5849(00)00419-6 